DOI 10.22460/infinity.v7i2.p183-190

\title{
PROBLEM-BASED LEARNING MODEL IN ELPSA FRAMEWORK ON MATHEMATICAL LEARNING PROCESS IN JUNIOR HIGH SCHOOL
}

\author{
Sukasno $^{1}$, Drajat Friansah ${ }^{2}$, Lucy Asri Purwasi ${ }^{3}$ \\ ${ }^{1,2,3}$ STKIP-PGRI Lubuklinggau, Mayor Toha St, Air Kuti, Lubuklinggau, South Sumatera, Indonesia \\ ${ }^{1}$ sukasno@gmail.com, ${ }^{2}$ drajatfriansah@ stkippgri-lubuklinggau.ac.id, \\ 3asripurwasi@stkippgri-lubuklinggau.ac.id
}

Received: June 04, 2018 ; Accepted: August 05, 2018

\begin{abstract}
The objective of this research was to find out the effectiveness of mathematical learning outcomes to the eighth-grade students after giving treatment by using the problem-based learning model. a preexperimental method was used in this research. The population of this research was all eighth-grade students of Junior High School. The number of the population was 103 students, while the sample was chosen randomly. The sample of this research was 33 students. Data collection was carried out using a test in the form of an essay. The results of this research showed that it was significantly effective to use problem-based learning model in ELPSA framework to the eighth-grade students of Junior High School. It was proved by the average score of the final test after giving treatment was 79.33 and the total number of students who completed the score was $78.79 \%$.
\end{abstract}

Keywords: Problem Based Learning, ELPSA, Mathematics.

\begin{abstract}
Abstrak
Penelitian ini bertujuan untuk mengetahui ketuntasan hasil belajar matematika Siswa Kelas VIII SMP Negeri Muara Kati Kabupaten Musi Rawas setelah diterapkan model Problem Based Learning Menggunakan Kerangka Kerja ELPSA. Metode yang digunakan dalam penelitian ini preeksperimental. Populasinya adalah seluruh siswa kelas VIII SMP Negeri Muara Kati sebanyak 103 siswa, sedangkan sampelnya dipilih satu kelas secara acak sebanyak 33 siswa. Pengumpulan data dilakukan dengan teknik tes berbentuk uraian. Hasil penelitian menunjukkan bahwa hasil belajar matematika siswa kelas VIII SMP Muara Kati setelah mengikuti pembelajaran matematika dengan model Problem Based Learning menggunakan kerangka kerja ELPSA secara signifikan tuntas. Ratarata nilai tes akhir setelah mengikuti pembelajaran sebesar 79,33 dan jumlah siswa yang tuntas mencapai $78,79 \%$.
\end{abstract}

Kata Kunci: Problem Based Learning, ELPSA, Matematika.

How to Cite: Sukasno, S., Friansah, D., \& Purwasi, L. A. (2018). Problem-Based Learning Model in ELPSA Framework on Mathematical Learning Process in Junior High School. Infinity, 7(2), 183-190. doi:10.22460/infinity.v7i2.p183-190. 


\section{INTRODUCTION}

Basically, Mathematics lessons are one of the required subjects which should be joined in the National Examination (NE), so students are required to study mathematics at school. The fact shows that the cognitive abilities possessed by each student are different, teacher's role is so crucial because it will help to get the ability to accept and absorb mathematics learning as expected by teachers. As it is stated Yuhasriati (2012) Mathematics is one of the basic sciences that plays an important role both in the development of science and technology and in shaping the human personality. However, mathematics is a complex subject and hard to be learned.

Based on prevoius study which was done to the eighth grade students and interview result to the teacher of mathematics, it was found out that there are several problems in learning process. They are students have not reached the minimum mastery criteria (MMC). The number of students who can achieve mastery learning in the daily math test only reached 46.67\%. Mathematical learning models was still conventional, and the lack of learning innovations used by the teacher in the learning process. In addition, Faradhilla, Sujadi, \& Kurwardi (2013) state that the selection of inappropriate learning approaches will lead to less effective learning development in the classroom so that it will become one of the causes of low learning outcomes.

To achieve the success of the learning process with Problem Based Learning model, it is necessary to use a systematic learning framework namely ELPSA learning framework (Experiences, Language, Pictures, Symbols, Application). Lowrie \& Patahuddin (2015) suggested that the ELPSA framework is a learning design which is cyclical. This design presents mathematical ideas through life experiences, mathematical conversations, visual stimuli, symbol notations, and knowledge applications. The argument is a benchmark for collaborating ELPSA framework with Problem-Based Learning learning model. Both of Problem Based Learning model and ELPSA are two concepts that have similarities in several stages, especially in extracting student learning experiences, where Problem Based Learning is a learning model that emphasizes two direction of learning and environment. According to Maharani \& Laelasari (2017), one of characteristics of PBL is to give students full responsibility for experiencing their own learning process directly. As it is also stated by Surya, Putri, \& Mukhtar (2017) that the learning process which facilitates students to solve problems based on everyday context can improve problem solving abilities.

According to Arifin (2015), ELPSA Framework is a model of learning design as a reference for teachers in designing lesson plan which gives students the opportunity to express learning experiences (experience), use language to describe experience (Language), visualize images to present experiences (Pictures), written symbolization to express experience in general (Symbols), and (Application) as the application of knowledge gained in solving various situations. In this learning design, teachers are encouraged to introduce concepts from what students comprehend (Lowrie \& Patahuddin, 2015).

Problem-Based Learning (PBL) model and ELPSA framework have similarities in terms of experience content so that by combining both of them, it is expected to create innovative, meaningful and memorable learning. It can improve students' learning outcomes in solving problems in mathematics learning. The adoption of the Problem Based Learning model in ELPSA framework consists of five main steps and each step in Problem Based Learning 
learning is used by ELPSA framework. The Problem Based Learning Model stages in ELPSA framework can be seen in Table 1 .

Table 1. Syntax of Problem Based Learning in ELPSA Framework

\begin{tabular}{ll}
\hline \multicolumn{1}{c}{ Stage } & \multicolumn{1}{c}{ Teacher's Behavior } \\
\hline $\begin{array}{l}\text { Stage 1 } \\
\text { Students' orientation on } \\
\text { problem }\end{array}$ & $\begin{array}{l}\text { Teacher explains the learning objectives, explains the logistics } \\
\text { needed, raises problems, motivates students to be involved in } \\
\text { solving selected problems. In this stage ELPSA framework is } \\
\text { used, namely the experiences that students have in relation to the } \\
\text { goals and problems given by the teacher. }\end{array}$
\end{tabular}

Stage 2

Organizing students for

The teacher helps students to define and organize learning tasks learning

Stage 3

Guiding individual or group investigations

Stage 4

Present and present the related to the problem

The teacher encourages students to gather appropriate information, carry out experiments, to get explanations and problem solving.

In this stage the ELPSA framework is Symbol and Application.

- Symbol aspects

Symbols involve students in presenting, constructing, and manipulating information in the form of symbols for problem solving in mathematics learning.

- Application Aspects

In Aspects This application states how understanding of symbols can be applied to new situations to get explanation and problem solving in mathematics learning.

results of the discussion

The teacher assists students in planning and preparing appropriate works such as reports, videos and models and helps them to share assignments with their friends. In this stage the ELPSA framework is used, namely Pictorial and Languange.

- This Pictorial Aspect relates to visual representation in presenting appropriate works such as reports and students presenting work in front of the class.

- The Languages Aspect is used appropriately in reporting information, presenting and presenting the results of discussions for understanding.

At this stage the teacher is only as a facilitator and provides input.

Stage 5

Analyze and evaluate

The teacher helps students to reflect or evaluate their the problem solving investigations and the processes they use

process

\section{METHOD}

The research method used in this study was a pre-experimental method. The experiment used was the Pretest and Postest Group design (Arikunto, 2013). 


\section{A $\mathrm{OXO}$}

where :

A: Random sample

$\mathrm{O}$ : Pretest $=$ posttest (test of learning outcomes)

$\mathrm{X}$ : The treatment of Problem Based Learning model learning using the EPLSA framework

The population of this study were all eighth grade students. Data collection was taken by using test. There were 6 question items by using problem-based and the items has fulfilled validity, realibility, level of difficulty and differentiation criteria.

\section{RESULTS AND DISCUSSION}

\section{Results}

Recapitulation of data from the pre-test and post-test results is shown in Table 2

Table 2. Result data of the Pre-test and Post-test

\begin{tabular}{clcc}
\hline No & \multicolumn{1}{c}{ Category } & Pre-test & Post-test \\
\hline 1 & Highest Score & 44 & 94 \\
2 & Lowest Score & 10 & 66 \\
3 & Average Score & 22,79 & 79,33 \\
4 & Classical Completeness & $0 \%$ & $78,79 \%$ \\
\hline
\end{tabular}

The results of the pre-test showed that the highest score was 44, the lowest score was 10 , and the average overall score was 22.79. Descriptively, it can be concluded that the initial ability of students before the implementation of mathematics learning with Problem Based Learning model in ELPSA framework was incomplete. While the post-test results show that the highest score was 94, the lowest score was 66, and the average score after giving treatment was 79.33, and the classical completeness was $78.79 \%$. So descriptively it can be concluded that the final ability of students after the implementation of mathematics learning by using Problem Based Learning model in ELPSA framework was included in the complete category.

When it was compared with pre-test data, the average score obtained by students was an increase of 56.54. In the pre-test there were no or $(0 \%)$ students who were completed and in the post-test there were 26 or $78.79 \%$ of students who completed after giving treatment by using Problem Based Learning model, using the ELPSA framework.

The average score and completeness of the learning pre-test and post-test can be seen in the Figure 1 


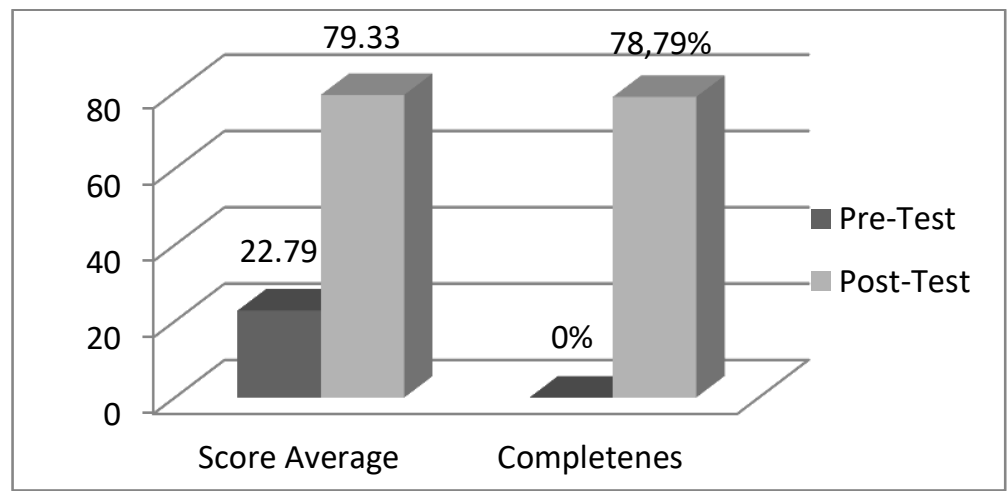

Figure 1. Average score of pre-test dan post-test

The results of the calculation of the normality test and t-test of the post-test data can be seen in Table 3 and 4.

Table 3. Result of Normality Testing

\begin{tabular}{ccccc}
\hline Data & $\chi^{2}{ }_{\text {obtained }}$ & Df & $\chi^{2}{ }_{\text {table }}$ & Conclusion \\
\hline Post-test & 6,72 & 5 & 11,07 & Normal \\
\hline
\end{tabular}

Table 4. Result of t-test

\begin{tabular}{cccccc}
\hline Data & $\boldsymbol{t}_{\text {obtained }}$ & Df & $\boldsymbol{\alpha}$ & $\boldsymbol{t}_{\text {table }}$ & Conclusion \\
\hline Post-test & 5,23 & 32 & 0,05 & 1,68 & $H_{0}$ rejected \\
\hline
\end{tabular}

Table 3 shows that the experimental class final test data was declared to be normally distributed. Because the data was normally distributed, then to test the hypothesis using the $\mathrm{t}-$ test. Based on the results of the t-test (table 4), t-obtained > t-table, it means that Ho was rejected and Ha was accepted. Thus the tested hypothesis can be accepted to be true so it can be concluded that the mathematical learning outcomes of the eighth grade students of Junior High School after the application of the Problem-Based Learning model using the ELPSA framework was significantly effective.

\section{Discussion}

The research was conducted at Junior High School. It was conducted in five meetings starting with the provision of a pre-test, followed by giving treatment by using Problem Based Learning model in ELPSA framework three times and giving of a post-test. In addition, in the initial learning activities, researchers first provided information about learning objectives and explain how to learn by applying Problem Based Learning model in ELPSA framework and explaining the learning steps to be implemented. Researchers divided students into seven heterogeneous groups based on the results of the pre-test. Students do activities by working on student worksheets $(\mathrm{SW})$ that contain problems.

Then, students' activities in groups with ELPSA framework after the teacher explores the experiences of students as follows: 
a. Students define and organize learning tasks related to the problem, in this case students begin to discuss the material contained in the worksheet. During group discussions students should actively seek information, construct new knowledge according to prior knowledge;

b. Students gather information that matches the form of symbols for problem solving, carry out experiments in expressing how the understanding of symbols can be applied to new situations such as everyday life, daily activities (application) to get explanation and problem solving;

c. One of the students represent the group presented the work in front of the class using teaching aids or pictures with the right language (languange) in the presentation, namely the language of mathematics or in other words the students as well as expressing mathematical symbols in language and oral form. After working on student worksheets (SW) students are asked to present the results to the class in a random way to move forward so that all groups must be prepared. Each advanced group is asked to hold discussions with other groups. To solve problems that arise during the discussion, the teacher appears as the main facilitator and resource person by explaining using existing media.

After being treated with Problem Based Learning model in ELPSA framework, Post-Tests were given as a benchmark for learning success. Based on the results of the Post-Test, the average value was 79.33. Hypothesis testing shows that $t$-obtained (5.23) $>t$ table (1.68). This proves the hypothesis in this study was accepted the truth. This result was in accordance with the results of research conducted by Arifin (2015) entitled "ELPSA Framework-Based Lesson Plan to build an understanding of the concept of addition and reduction of students' integers". The results of his research show significant results where students are able to make relationships between concepts, present concepts in various mathematical representations. It means that understanding the concept can increase significantly after giving treatment by using ELPSA framework.

ELPSA framework starts from connecting students' previous experience to the new learning, giving students the chance to express their own finding, and building visual thinking of students to the presentation of ideas using symbols (Johar \& Hajar, 2016). That is, when teaching practice allows students to develop mathematical ideas that are associated with their experiences or knowledge, and engage in discussions of mathematical ideas with other people, then the possibility of introducing the concept is significantly greater. Applicationbased learning is beneficial for students in solving new problems, it was also supported by Yew \& Goh (2016) which its effectiveness on the quality of student learning and the extent to which its promise of developing self-directed learning habits, problem-solving and deep disciplinary knowledge.

\section{CONCLUSION}

Based on the results of the research and discussion, it can be concluded that mathematics learning outcomes to the eighth grade students of Junior High School after giving treatment by using Problem Based Learning (PBL) model in ELPSA framework is significantly effective, with t-obtained $(5.23)>\mathrm{t}$-table $(1,68)$. The average score of the final test after giving treatment is 79.33 and the number of students who achieve learning completeness are $78.79 \%$. On the other hand, the limitation was the students still have limitations in solving complex story problems. 


\section{REFERENCES}

Arifin (2015). Lesson Plan Berbasis Kerangka Kerja ELPSA untuk Membangun Pemahaman Konsep Penjumlahan dan Pengurangan Bilangan Bulat pada Siswa. Jurnal Kependidikan, 1-20.

Arikunto, S. (2013). Prosedur Penelitian. Jakarta: Rineka Cipta.

Faradhilla, N., Sujadi, I., \& Kurwardi, Y. (2013). Eksperiment Model Pembelajaran Missouri Mathematics Project (MMP) Pada Materi Pokok Luas Permukaan Serta Volume Prisma dan Limas Ditinjau dari Kemampuan Spasial Siswa Kelas VIII Semester Genap SMP Negeri 2 Kartasura Tahun Ajaran 2011/2012. Jurnal Pendidikan Matematika Solusi, 1(1), 67-74.

Johar, R., \& Hajar, S. (2016). Implementation of ELPSA Framework in Teaching Integral Using Technology. International Journal of Science and Applied Technology, 1(1), $15-21$.

Lowrie, T., \& Patahuddin, S. M. (2015). Elpsa As A Lesson Design Framework. Journal on Mathematics Education, 6(2), 1-15.

Maharani, A., \& Laelasari (2017). Experimentation of Spices Learning Strategies With The Method of Problem Based Learning (PBL) to Build Motivation and The Ability to Think Logically for Vocational School Students. Infinity, 6(2), 149-156.

Surya, E., Putri, F. A., \& Mukhtar (2017). Improving Mathematical Problem-Solving Ability and Self-Confidence of High School Students Through Contextual Learning Model. Journal on Mathematics Education, 8(1), 85-94.

Yew, E. H., \& Goh, K. (2016). Problem-Based Learning: An Overview of its Process and Impact on Learning. Health Profession Education, 2(2), 75-79.

Yuhasriati (2012). Pendekatan Realistik dalam Pembelajaran Matematika. Jurnal Peluang, $1(1), 81-87$. 
190 Sukasno, Friansah, \& Purwasi, Problem-Based Learning Model in ELPSA Framework ... 